\title{
Global Stars on Local Screens: BTS and Its "Army"
}

\author{
Rozália Klára BAKÓ \\ Sapientia Hungarian University of Transylvania \\ Cluj-Napoca, Romania \\ E-mail: bakorozalia@uni.sapientia.ro
}

\begin{abstract}
This research note is aimed at exploring the opportunities and challenges faced by teenagers living in an underprivileged region in Romania as fans of an internationally popular K-pop band. We used desk research and netnography to explore similarities and differences between the local and international BTS (Bangtan Sonyeondan) fandom, also called "Army". Which are the barriers a Hungarian "Army" from Romania encounters when engaging with their idols? What is the role of K-pop in opening up the language and cultural bubble in which Hungarian youth in rural Romania live? ${ }^{1}$ The innovative element in our empirical research is the focus on family context: we interviewed both BTS fans and their parents in order to assess to what extent is K-pop in general and BTS in particular part of their daily lives. With its limitations as a small-scale qualitative analysis, such research can give insights into fan studies from a comparative perspective.
\end{abstract}

Keywords: K-pop, Hungarians from rural Romania, cultural bubble, BTS fandom

\section{Introduction}

Korean pop music (K-pop) is gaining popularity worldwide as part of the cultural phenomenon called Hallyu (Korean Wave). The term, coined by the Chinese media to express the rising appeal of the Korean popular culture in Asian countries, epitomizes what Kim (2013) defined as the Asian reaction to a Western-dominated globalization:

In contemporary Korean cinemas, TV dramas and pop music, globalization is also evident. The stars follow the world trend in performance, presentation and fashion [...]. English is often used as lyrics in songs. However, the big difference is that the performers have distinct Asian physical features, and

1 Funded by Sapientia Foundation - Institute for Research Programmes, Romania. 
the dramas reflect the traditional Asian values and ethos, which helps to make the Asian fans feel at home. The "Asian-ness" is no longer something weird or marginal, but takes center stage. (Kim, 2013: 135)

The diffusion of Korean popular culture across the world started in the midnineties, and it is an ongoing process facilitated by globalization and social media (Huang, 2017). In Romania, Hallyu penetrated relatively late, starting from 2009 with K-dramas and from 2011 with K-pop. The first Korea-fan meeting was held in Bucharest in 2010 (Marinescu-Balica, 2014: 91). ${ }^{2}$ Kim (2015) presented the three main periods of Hallyu and its gradual expansion, as summarized in the table below:

Table 1. Diffusion of the Korean Wave across the world

\begin{tabular}{llll}
\hline \multicolumn{1}{c}{ Stages } & \multicolumn{1}{c}{ Hallyu 1.0 } & \multicolumn{1}{c}{ Hallyu 2.0 } & \multicolumn{1}{c}{ Hallyu 3.0 } \\
\hline Period & 1995-2005 & 2006-2015 & From 2016 onwards \\
\hline $\begin{array}{l}\text { Diffusion } \\
\text { area }\end{array}$ & $\begin{array}{l}\text { Asia (China, Taiwan } \\
\text { Japan) }\end{array}$ & $\begin{array}{l}\text { Asia, North } \\
\text { America, Europe }\end{array}$ & All over the world \\
\hline Target & $\begin{array}{l}\text { K-dramas and } \\
\text {-movies }\end{array}$ & $\begin{array}{l}\text { K-pop idols, star- } \\
\text { oriented }\end{array}$ & $\begin{array}{l}\text { Diversification, } \\
\text { brand-oriented }\end{array}$ \\
\hline $\begin{array}{l}\text { Early } \\
\text { distribution }\end{array}$ & Overseas Korean & $\begin{array}{l}\text { Online circulation } \\
\text { (YouTube) }\end{array}$ & $\begin{array}{l}\text { Social media } \\
\text { (Twitter, FB, IG) }\end{array}$ \\
\hline Media & Video, CD, & $\begin{array}{l}\text { Internet, on-site } \\
\text { performance }\end{array}$ & Cross-media \\
& broadcasting & Overseas & Worldwide \\
Focus & The world should & $\begin{array}{l}\text { K-expansion } \\
\text { mainstreaming }\end{array}$ \\
\hline
\end{tabular}

In his interpretation, the Korean Wave is a form of soft power spreading peacefully across the global village (Kim, 2015: 160). K-drama and K-pop are the main vectors of the Hallyu phenomenon, and all my teenage interviewees were fans of both: listening to many other K-pop groups while preferring BTS and watching ardently Korean dramas. In this article, we will be focusing on the K-pop fandom, with a highlight on BTS "Army". The acronym ARMY stands for Adorable Representative MC for Youth: "the BTS global fan base of millions of loyal followers is powerful enough to create major waves" (SeoHollingsworth, 2019).

Not all BTS fans are K-pop fans though. Sherliza Moé, an influencer from Austria, a BTS fan, and a critical voice of the K-pop phenomenon, put it bluntly:

2 Japanese and Chinese cultural diplomacy were more advanced in the country through martial arts and music. 
All my friends were super into K-pop and I don't know, I just didn't find it that interesting. [...] There were some songs that were kind of catchy and I'd listen to them, but I could never fully get the appeal of K-pop. Something about it just looked and felt off. All these boys and girls who dance perfectly synchronized, those perfect basic doll-faces, those copypaste beats, manufactured hooks... I don't know: something about these music videos and people felt kind of fake, hollow, and uninspired. (Sherliza Moé, 2018a: 0:28-1:11)

Beyond her gut feeling, Moé started digging systematically into the dark side of the pop industry: ${ }^{3}$ how do young people become idols? By training to be talented - but is that even possible? Taking dancing, singing, and acting classes and most importantly, at the entry level, to have the looks. What is there to admire when it is just the outside that looks good? It is all manufactured - these opinions echoed in one interviewee fathers' words as well. If this music is so "mediocre" and "fake", how did Sherliza Moé become a BTS fan? Why did she attend three concerts? How does anybody become a fan? Is it the ubiquitous social media? Is it through friends?

Social media has radically changed the spaces of engagement with popular music, leading to a shift from local subcultures to translocal and global interactions (Tófalvi, 2011). The process of creation, distribution, and consumption of culture in general and popular music in particular has shifted from a music-show-centric approach and the dominance of big music labels to a complex business model engaging talent management, multimedia distribution channels, and a carefully planned digital marketing with fandom engagement at its centre.

\section{Methodology}

The exploratory case study on BTS and its local and global fandom started on 25 May and was completed on 31 October 2020, combining desk research and empirical analysis. We interviewed six BTS fans and their parents (the five families were selected upon criteria of availability and variety in a rural area from Central Romania, inhabited mainly by Hungarians) and followed systematically six savvy influencers with critical views on K-pop - meanwhile BTS fans. Such a contrastive approach is aimed at highlighting the socio-cultural gap between a privileged and an underprivileged fandom: the influencers in their twenties,

3 The harsh treatment K-pop trainees are subjected to, the slave contracts they are forced to sign for up to ten years, and their underpayed efforts are often mentioned. Predator business practices of talent management companies led to court cases and media scandals, highlighted by influencers under study. Big Hit Entertainment is presented in a positive light, with more creative freedom given to artists. 
belonging to the older and independent generation $\mathrm{Z}$ versus the teenager fans, dependent on their parents. Five YouTube channels' and five families' BTSrelated approach was compared in order to explore how the global and local fandom intertwines and differs.

Research was carried out online, during the Covid-19 restrictions: a literature review on K-pop and fandom studies, ten semi-structured interviews (fans and parents) as well as a content analysis of BTS-related posts of international "Army" influencers followed via YouTube from June to October 2020. The influencers were carefully selected after screening popular BTS-related, English-speaking YouTube channels: Farina Behm's channel (Farina Jo - 897,000 subscribers) from Germany; Cameron Philip K from Canada, with 676,000 subscribers; Danny Kim and David Kim's channel (DKDKTV) from Korea, with 697,000 subscribers; Dave Disci from the United States, with 191,000 subscribers; Sherliza Moé from Austria, with 553,000 subscribers. They epitomize the privileged, international fandom with a high level of visibility online. Meanwhile we screened closely BTS-related content on Big Hit Entertainment (BHE) ${ }^{4}$ official YouTube and Twitter channels concerning company events in order to understand the business model and talent management philosophy leading to BTS success. During September and October 2020, more than 120 hours of BTS-related influencer and BHE videos were screened for relevant content and for a better understanding of the global K-pop fandom phenomenon.

Table 2. BTS fans under study

\begin{tabular}{llll}
\hline Name or alias & Status & $\begin{array}{l}\text { Gender and } \\
\text { age }\end{array}$ & Method \\
\hline 1. Anna (alias) - Bahrein ${ }^{5}$ & interviewee & Female, 15 & $\begin{array}{l}\text { Video interview } \\
\text { analysis + mother's }\end{array}$ \\
\hline 2. Erika (alias) - Romania & interviewee & Female, 19 & $\begin{array}{l}\text { Phone interview } \\
\text { analysis + mother's }\end{array}$ \\
\hline 3. Kitti (alias) - Romania & interviewee & Female, 13 & $\begin{array}{l}\text { Phone interview } \\
\text { analysis + mother's }\end{array}$ \\
\hline 4. Mari (alias) - Romania & interviewee & Female, 16 & $\begin{array}{l}\text { Phone interview } \\
\text { analysis (Kitti’s sister) }\end{array}$ \\
\hline 5. Lily (alias) - Romania & interviewee & Female, 12 & $\begin{array}{l}\text { Phone interview } \\
\text { analysis + father's }\end{array}$ \\
\hline 6. Mira (alias) - Romania & interviewee & Female, 12 & $\begin{array}{l}\text { Phone interview } \\
\text { analysis + father's }\end{array}$ \\
\hline 7. Farina Behm (Germany) & influencer & Female, 27 & $\begin{array}{l}\text { YouTube, 15 video } \\
\text { analyses }\end{array}$ \\
\hline
\end{tabular}

4 The Korean company that discovered, trained, and manages BTS.

5 Her mother moved abroad from Romania. Anna still has roots here and speaks her native Hungarian language. 


\begin{tabular}{|c|c|c|c|}
\hline Name or alias & Status & $\begin{array}{l}\text { Gender and } \\
\text { age }\end{array}$ & Method \\
\hline 8. Dave Disci (US) & influencer & Male, 25 & $\begin{array}{l}\text { YouTube, } 34 \text { video } \\
\text { analyses }\end{array}$ \\
\hline 9. Danny Kim (Korea) & influencer & Male, 28 & \multirow{2}{*}{$\begin{array}{l}\text { YouTube, } 13 \text { video } \\
\text { analyses }^{6}\end{array}$} \\
\hline 10. David Kim (Korea) & influencer & Male, 28 & \\
\hline 11. Sherliza Moé (Austria) & influencer & Female, 23 & $\begin{array}{l}\text { YouTube, } 22 \text { video } \\
\text { analyses }\end{array}$ \\
\hline $\begin{array}{l}\text { 12. Cameron Philip K } \\
\text { (Canada) }\end{array}$ & influencer & Male, 24 & $\begin{array}{l}\text { YouTube, } 48 \text { video } \\
\text { analyses }\end{array}$ \\
\hline
\end{tabular}

Teenagers were asked about the history and the status of their fandom, their daily fangirling routines, their favourite BTS members and songs, whether they bought or plan to buy any related products, whether they follow BTS on social media, and what kind of BTS-related content they prefer. An important part of the interview was the impact BTS has on their lives and why they think BTS is so popular. We also carried out follow-up discussions with the teenagers. Upon request, two of the six interviewees sent pictures with various BTS products they bought. Parents were interviewed via Facebook Messenger: mothers (of Anna, Erika, Kitti, and Mari) and fathers (of Lily and of Mira), ${ }^{7}$ by asking them four questions: (1) How much do they know about BTS based on their daughter's fan behaviour? (2) How much do they like or dislike BTS? (3) Did Korean music and BTS have an impact on their daughter? (4) Why do they think BTS has so many fans?

Based on the interviewees' and the influencers' discourses, we created three categories of engagement: entertainment-oriented, cultural, and professional. Entertainment-oriented engagement refers to a mainly consumerist attitude towards BTS-related content be it music, live streaming, reality shows, or memes and fan art. A cultural engagement describes a broader interest in Korean culture, going beyond kimchi: language, history, habits, and iconic places.

An element of the study was auto-ethnography: from mid-May to the end of October, the author was a participant observant of BTS Army life: commented on YouTube videos, streamed the new hit Dynamite to promote it on the international charts, and watched BTS-related content online: reality shows, interviews, memes as well as fan fiction. This part of the research was less rigorous given the "plethora of apps on mobile devices, a range of social media platforms, and highly individualized engagement patterns ${ }^{8}$ [giving] rise to uncertainty, complexity, and the feeling that something is always being missed"

$6 \quad$ They are friends and colleagues, not brothers, as some netizens think. They post together and separately too.

$7 \quad$ Lili and Mira are cousins living in different small towns, fangirling together both on- and offline.

8 I learned the BTS fanchant (the boys' names) and had a bias (favourite group member): RM. 
(Popova, 2020: 3.2). However, it gave a glimpse of the fandom spirit and the rich media content available on the boy band.

\section{Bangtan Sonyeondan: The Brightest K-Pop Star}

When she newly discovered the boy band, Sherliza Moé has found their music mediocre. "I am not a fan of pop music in general [...] I don't think it is bad or something, just mediocre. But that does not mean I don't jam to it, that I don't listen to it” (2019: 20:27-20:43). Two of the interviewed teenagers - Kitti and Lili - had the same first impression when they started listening to K-pop and BTS. After getting immersed in their music and the stories built around it, after they encountered group members - even if only virtually -, their perception has changed radically, just like in the case of Sherliza.

I watched a video, then another video, and I kinda got sucked into the fandom [...] I really tried not to like them, but it's hard [...] I'm not the biggest fan of their music, it sounds pretty mediocre [...] It sounds like many other pop songs [...] But I do appreciate the fact that some members are involved in the songwriting [...] Most K-pop bands sing about superficial topics like looking pretty, partying, making somebody falling in love with them. (Sherliza Moé, 2018b: 1:03-1:11)

Bang Si-Hyuk, leader of Big Hit Entertainment and the "founding father" of BTS, explains in an interview the secret of the band's appeal: communication with fans on a more personal level and a constant effort to convey a positive message (Song, 2020). Bangtan Sonyeondan - literally meaning Bulletproof Boy Scouts - formed in 2010 and debuted in 2013; they were a hip-hop group first and later playing a mixed genre. ${ }^{9}$ It has seven members: Kim Namjoon (RM), Kim Seokjin (Jin), Min Yoongi (Suga), Jung Hoseok (J-Hope), Park Jimin (Jimin), Kim Taehyung (V), and Jeon Jungkook (Jungkook). As Romano (2020) put it, the key to the Bangtan Boys' success is resonance, sincerity, and an army of fans. From 2017 onwards, BTS broke records in terms of performance and popularity, winning several awards nationally and internationally (Bensley, 2020) - more recently with their all-English single Dynamite in August 2020. "BTS is the product of an industry insider who wanted to create a new kind of idol" - summarizes Romano.

In order to understand the background of such results, it is worth mentioning the way talent management companies work in Korea: "While record labels, artist management companies, and talent agencies operate as separate entities in

With EDM, R\&B, and rap dosed differently in each song. 
America, Korean entertainment companies are a configuration of all three [...] a hybrid, highly integrated cultural technology" (Nguyen, 2020).

Beyond this enabling context and the state support for the cultural export of K-pop, the reason behind the BTS's meteoric success was the smart and systematic use of social media to build up a personalized yet well-controlled relationship with its fan base. Spontaneity, playfulness, and charisma on the stage combined with gratitude towards their fans lifted the "bulletproof scouts" to the top of international and national ranks and magnified them via online interaction. According to the official K-pop ranking in September 2020, ${ }^{10}$ BTS was on the first place both individually and as a group. Ranking was based on consumer participation (sales), interaction (communication with fans and the media), and community (fan base).

Chang and Park (2019: 260) identified four primary dimensions of this mainly online fandom: (1) digital intimacy, (2) non-social sociality, (3) transnational locality, and (4) organizing without an organization. All these elements are related to the network effect of the Internet and the global access to digital content, with the advantages of comfort, speed, and affordability and the disadvantage of mediality ("I watch their videos every day" - Anna, Kitti, Lily, and Mira reported). There is also the risk of oversaturation and commercialization of online media content, experts warn (Reinhardt, 2020). They also coagulate ARMY into "tribes" - transnational fans connected by their common idols and the English language as well as local ones connected by local languages. Indeed, the five teenagers interviewed were mostly connected to Hungarian-language content produced in Hungary and some YouTube and Instagram videos translated into English.

Social media interaction of BTS members with their fans is highly controlled by their management, Big Hit Entertainment (BHE): Twitter is the main and official social media platform with a company account and one common account for the seven members of the boy band. However, fans are creating a plethora of videos, memes, fan fiction, and animations featuring the whole band or their favourite members. BHE also created a dedicated platform called Weverse through its subsidiary tech company beNX for synchronous and asynchronous interactions between idols and fans, with over 7 Million BTS fans as of October 2020 (Benjamin, 2020). The advantage is the higher profit margin on content and product selling on its own platform and data ownership, thus a better control.

\section{Global Fans: Influencers as Prosumers}

Each of the five influencers selected for this study are immersed in BTS fandom, creating video content such as MV reactions, BTS music covers (Cameron), K-poprelated documentaries (Danny and David, Farina Jo, Sherliza), live streamings

10 https://kpopofficial.com/top-50-kpop-popularity-reputation-ranking-september-2020/. 
from BTS concerts (Danny and David, Farina Jo, Sherliza), meme reviews (Dave), and fan fiction (Cameron). Learning about K-pop and BTS was a refreshing cultural experience during lockdown.

Meanwhile, following the five YouTube channels was the most entertaining part of the empirical research: a daily sip of witty K-pop and BTS gossip with Dave Disci, hilarious fan fictions with Cameron Philip K, concert live streams with DKDKTV, Farina Jo and Sherliza Moé, and reactions, memes: never would I have imagined that studying K-pop was such an entertaining endeavour. In order to understand the "Army" bubble, I had to learn the insiders' language - keywords and slang mostly fans can understand. ${ }^{11}$ There are also difficulties related to the complicated Korean cultural background of the BTS music videos, not only insider language or the lack of translation from Korean into English. A "cultural translation" is also needed, and DKDKTV aims at providing it. As Danny Kim explained in the Arirang TV studio (2019): "We try to bridge the gap of cultural differences between Korean and international fans of K-pop”.

The agencies "know exactly what the audience wants. They have special concepts for each group because they want them to make it in this super saturated market. I think that aspect makes the groups strive for different things and it makes K-pop scene interesting”, said Danny Kim in an interview (Park, 2018). Due to their creativity as content producers and their high connectivity with like-minded audiences, the influencers under study are receptive to cultural movements across the K-pop industry; they care and are knowledgeable. Their videos are well prepared, even if they put on a laid-back mask: the content is informative and mostly well thought. Their level of involvement as BTS fans is different: the most dedicated is Cameron, a loyal Army since the group was formed, whereas Danny and David got immersed in BTS fandom through their cultural ambassador work as K-pop translators from Korean into English. Dave and Sherliza are witty K-pop commentators, almost stand-up comedians, while Farina Jo's engagement has a strong personal character: her Korean partner is a BTS fan as well, and she acts as a cultural interpreter of K-pop and Korean lifestyle.

Through their active audience involvement, these YouTubers strengthen BTS's participatory fan activism, gathering a fan base themselves and giving an extra boost to their band's Army (Jung, 2012). It is both for the good and for the bad since comments are often offensive, and they complained of receiving hate and death threats online.

11 If you are a BTS fan, you can decode "Lachibolala”, “NamJin”, “TaeKook”, "Sasaeng”, or "delulu" - to name but a few. 


\section{Local Fans: A Shy Army}

Language is a serious barrier when it comes to local BTS fandom, and cultural differences add to it, as other studies confirm from Canada (Yoon, 2019), Latin America (Min-Jin-Han, 2018), and Poland (Trzcinska, 2018). All teenagers interviewed had English as their third or second language although Anna, Kitti, Lili, and Mira started to learn Korean as an impact of watching BTS music videos that they wanted to understand better. It seemed to be too difficult, and Kitti gave up, while the others just slowed down.

Since there is so much BTS content available online, the language barrier seems to be frustrating for many fans, not only for those interviewed. Comments on the BHE official YouTube channel often asked for English translation, especially for interviews and live streams. Initial access to BTS, the first contact with the Korean band was either via a friend (Anna, Mira) or a family member (sister - Erika, Kitti, and cousin: Lily). Social media played a catalyst role, though, by offering BTSrelated content through its algorithms. Out of the five parents interviewed, only one (Lily's father) seemed to be more knowledgeable in K-pop and BTS, while Anna's, Kitty's, and Erika's mother had a very vague idea on this music and the band. Mira's father was well-informed about K-pop industry and was rejective towards it, although knew little details about BTS.

All parents interviewed expressed their satisfaction that BTS opened their daughter's cultural horizon and their interest towards Korea in general: language, food, customs, and lifestyle. As for BTS as a band, three of five parents declared that they would hardly recognize any of their songs or know the members' names. The dislikes came from their feminine appearance, not the music: "It is pleasant, I can listen when Erika is listening." Mira's father has definitely rejected K-pop as a genre, considering it too manufactured and commercial however, if his daughter would ask him, he would take her to a BTS concert when they come to Romania.

In terms of purchasing products, only Anna had the privilege to visit Korea, and she travelled to a country where she had fast access and financial resources to buy several valuable objects: albums, plush dolls, posters (Picture 1), and she had the opportunity to go to a BTS concert. Mira's father reported that his wife visited Korea and bought BTS-related products: shirts and small memorabilia, to the great satisfaction of their daughter. 

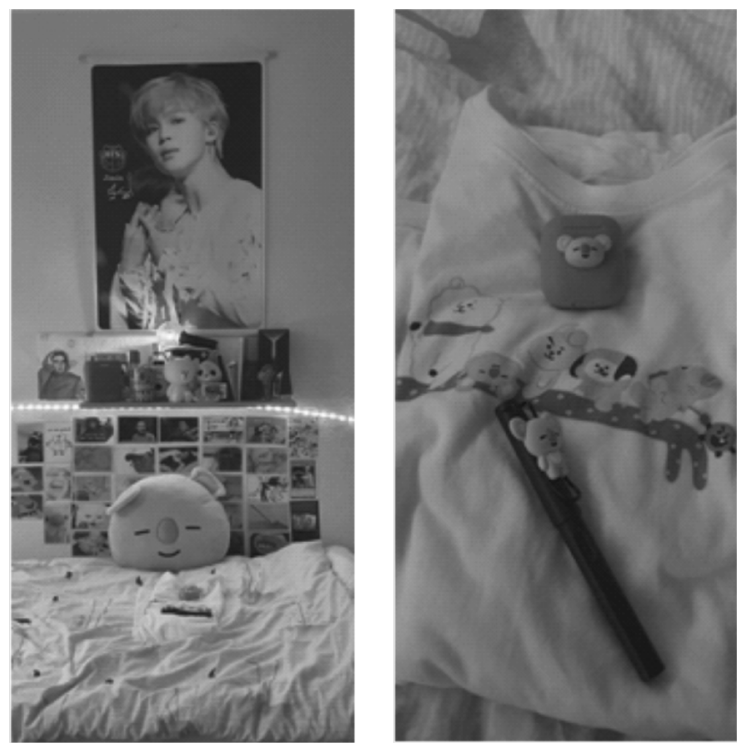

Picture 1-2. Anna's room with her idol, Jimin (left), and small items ${ }^{12}$ (right)

Kitti also bought BTS-related memorabilia: school bag, pencil case, mask, hoodie, and an Army Bomb (a light stick for concerts, although she never could get a ticket to one).

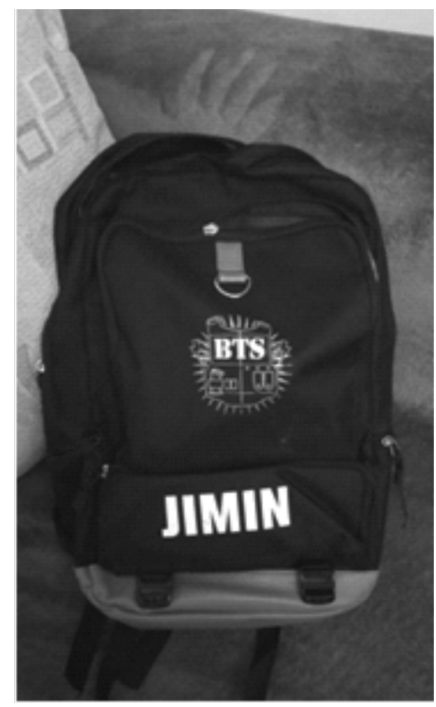

Picture 3. Kitti's schoolbag with her idol, Jimin

12 The little animals available as animations and plush dolls, each designed by a member of BTS, are very popular. 
There are significant differences between the teenagers interviewed in terms of involvement, daily routines, and updates related to BTS. The most involved and knowledgeable were Anna, Lily, and Mira, while Erika and Kitti were less informed about the band.

All interviewees had at least a three-year history with the band, and all expressed some level of interest towards Korean culture (K-dramas and other K-pop bands, such as Stray Kids, and kimchi). It came as no surprise that in terms of social media engagement Anna was the most present one on all platforms where BTS content was available: Twitter - the main account of the band, YouTube, Instagram, and Weverse. I was surprised by the lack of interactivity of the girls on social media, and one explanation given was the language barrier: they could understand English but were not very confident to write. The more consistent their interest and engagement with the band was, the greater interest and broader cultural horizon the local teenage fans had.

\section{Fandom Engagement: The Global and the Local}

If we look into influencers' and interviewees' discourses, striking similarities and expectable differences unfold: consistent engagement with K-pop in general and with BTS in particular led to a broader cultural perspective, as shown in the summary table below.

Table 3. BTS fans and their engagement

\begin{tabular}{lll}
\hline Name or alias & $\begin{array}{c}\text { Level and type of } \\
\text { engagement }\end{array}$ & \multicolumn{1}{c}{ Description } \\
\hline 1. Anna (alias) & $\begin{array}{l}\text { High, entertainment } \\
\text { and cultural }\end{array}$ & $\begin{array}{l}\text { Daily engagement, informed, went } \\
\text { to concert, speaks and writes Korean } \\
\text { (basic), visited Korea. }\end{array}$ \\
\hline 2. Erika (alias) & Low, entertainment & $\begin{array}{l}\text { Basic BTS knowledge, listens favourite } \\
\text { tracks but not daily, open interest } \\
\text { towards K-drama. }\end{array}$ \\
\hline 3. Kitti (alias) & $\begin{array}{l}\text { Medium, } \\
\text { entertainment }\end{array}$ & $\begin{array}{l}\text { Informed, bought products, started to } \\
\text { learn Korean, influenced by friend and } \\
\text { sister. }\end{array}$ \\
\hline 4. Mari (alias) & Low, entertainment & $\begin{array}{l}\text { Informed, used to be a fan, influenced } \\
\text { her younger sister, general interest } \\
\text { towards K-pop. }\end{array}$ \\
\hline 5. Lily (alias) & $\begin{array}{l}\text { High, entertainment } \\
\text { and cultural }\end{array}$ & $\begin{array}{l}\text { Daily engagement, informed, cooked } \\
\text { kimchi, started to learn Korean (basic), } \\
\text { bought products. }\end{array}$ \\
\hline
\end{tabular}




\begin{tabular}{lll}
\hline Name or alias & $\begin{array}{l}\text { Level and type of } \\
\text { engagement }\end{array}$ & \multicolumn{1}{c}{ Description } \\
\hline 6. Mira (alias) & $\begin{array}{l}\text { High, entertainment } \\
\text { and cultural }\end{array}$ & $\begin{array}{l}\text { Daily engagement, informed, cooked } \\
\text { kimchi, started to learn Korean (basic), } \\
\text { bought products. }\end{array}$ \\
\hline $\begin{array}{l}\text { 7. Farina } \\
\text { Behm }\end{array}$ & $\begin{array}{l}\text { High, entertainment } \\
\text { and cultural }\end{array}$ & $\begin{array}{l}\text { Informed, went to three concerts, learns } \\
\text { Korean for personal reasons, creates } \\
\text { BTS-related content. }\end{array}$ \\
\hline 8. Dave Disci & $\begin{array}{l}\text { High, entertainment } \\
\text { and cultural }\end{array}$ & $\begin{array}{l}\text { Informed, creates K-pop-related content } \\
\text { daily, rich BTS-related YouTube content } \\
\text { (over 800 videos). }\end{array}$ \\
\hline 9. Danny Kim & $\begin{array}{l}\text { Medium, } \\
\text { professional and } \\
\text { cultural }\end{array}$ & $\begin{array}{l}\text { Went to two BTS concerts, explains } \\
\text { background meaning of BTS music } \\
\text { videos, explains K-pop. }\end{array}$ \\
\hline 10. David Kim & $\begin{array}{l}\text { Medium, } \\
\text { professional and } \\
\text { cultural }\end{array}$ & $\begin{array}{l}\text { Went to two BTS concerts, explains } \\
\text { background meaning of BTS music } \\
\text { videos, explains K-pop. }\end{array}$ \\
\hline 11. Sherliza & $\begin{array}{l}\text { Medium, } \\
\text { entertainment and } \\
\text { cultural }\end{array}$ & $\begin{array}{l}\text { Went to three BTS concerts, engages } \\
\text { in critical debates on K-pop and BTS. } \\
\text { Other topics prevail. }\end{array}$ \\
\hline 12. Cameron & $\begin{array}{l}\text { High, entertainment } \\
\text { and cultural }\end{array}$ & $\begin{array}{l}\text { Created several BTS song remixes (with } \\
\text { one remarked by BTS), fan art, reaction } \\
\text { videos. }\end{array}$ \\
\hline Philip & &
\end{tabular}

A high level of fandom engagement is related to a broader interest in K-pop and to a variety of idol-related activity, be it going to concerts (for the privileged, both local and global fans) or buying products, getting immersed in Korean culture, and staying informed in BTS matters - both globally and locally.

\section{Conclusions}

Cultural production and consumption habits have changed radically with the rise of new media, and pop music is a mix of genres that is gaining popularity and appreciation worldwide, even if there is still a lack of acceptance and openness towards it (Batta, 2011).

There is a significant difference between local and global fans, the former ones having a good command of English (Sherliza, Danny, and David) or being native speakers (Dave and Cameron). For Hungarian young people living in rural areas of Romania and in ethnic bubbles (Bakó, 2019), a cultural trip to Korea is more difficult yet refreshing and mind-opening: parents' and interviewees' opinions were consonant. 
For influencers living in big cities (Toronto, New York, Vienna, Frankfurt, and Seoul), a multicultural environment is more familiar, and yet even they have their own bubbles. For Danny and David, the cultural trip was Los Angeles, with its infinitely more diverse fandom at the BTS concert. Bubbles might also be useful: without their cultural translation of Agust D's ${ }^{13}$ Daechwita, little would I have understood from the deep historical roots of the song.

As for the author immersed in the role of an Army, it was a refreshing and interesting research experiment. BTS and its fandom created meaningful multimedia content to explore. "They are so entertaining to watch!" - conceded Sherliza Moé (2018: 7:38). McLarren and Jin (2020) said the same: you cannot help but love them. Agreed.

\section{References}

Arirang T. V. (2019). The Inner View:DKDKTV.<https://youtu.be/d5CBm1ynG0M> (accessed on: 12 June 2020).

Bakó, R. K. (2019). Digital Naïves Go Online. Acta Universitatis Sapientiae, Communicatio 6: 121-129. DOI: 10.2478/auscom-2019-0007.

Batta, B. (2011). A pop védelmében. A kultúra előállításának és fogyasztásának új logikája [In Defence of Pop. The New Logic of Cultural Creation and Consumption]. In: Tófalvi, T.-Kacsuk, Z.-Vályi, G. (eds.), Zenei hálózatok. Zene, müfajok és közösségek az online hálózatok és az átalakuló zeneipar korában [Music, Genres and Communities in the Age of Online Networks and a Transforming Music Industry]. Budapest: L’Harmattan, 308-322.

Benjamin, F. (2020). Why K-Pop Content Creators Are Leaving YouTube and V-Live. <https://www.billboard.com/articles/deep-dive/9332981/why-k-popcontent-creators-are-leaving-youtube-and-v-live > (accessed on: 12 June 2020).

Besley, A. (2020). BTS: Icons of K-Pop. London: Michael O’Mara Books Limited.

Cameron, Philip K. (2020). BTS. (accessed on: 15 October 2020). https://www. youtube.com/playlist?list=PLq1oDlKeR_iAxEbc--oHHZP31gdetW_q6.

Chang, W. J.-Park, S. E. (2019). The Fandom of Hallyu, a Tribe in the Digital Network Era. The Case of Army of BTS. Kritika Kultúra 32: 260-287.

Dave Disci Vlogs. (2020). K-Pop Reaction. (accessed on: 15 October 2020). https:// www.youtube.com/playlist?list=PLZoa606CYo04CB8dxEJDNEN4derVT8skB.

DKDKTV. (2020). K-Pop Explained by a Korean. (accessed on: 15 October 2020). https://www.youtube.com/playlist?list=PLq0bxUK0D1Ka0fjbSueBYdo_ ehzZsfWU3.

Farina, Jo. (2020). BTS. (accessed on: 15 October 2020). https://www.youtube. com/playlist?list=PLFysom2ASGuSos2nl1ZUoN_npKJodGbGa.

13 Min Joongi (Suga) as an independent artist. 
Huang, S. (2017). Social Media and the New Korean Wave. Media, Culture $\mathcal{E}$ Society 39(5): 773-777.

Jung, S. (2012). Fan Activism, Cybervigilantism, and Othering Mechanisms in K-pop Fandom. In: Jenkins, H.-Shresthova, S. (eds.), Transformative Works and Fan Activism - Special issue. Transformative Works and Cultures 10. https://doi.org/10.3983/twc.2012.0300.

Kim, B. R. (2015). Past, Present and Future of Hallyu (Korean Wave). American International Journal of Contemporary Research 5(5): 154-161.

Kim, H. (2013). The Korean Wave: An Asian Reaction to Western-Dominated Globalization. Perspectives on Global Development and Technology 12(1-2): 135-151.

Marinescu, V.-Balica, E. (2014). Audience Perceptions and Representations of Korea. The Romanian Experience. In: Marinescu, V. (ed.), The Global Impact of South Korean Popular Culture. Hallyu Unbound. Lanham-Boulder-New York-London: Lexington Books, 89-104.

McLaren, C.-Jin, D. Y. (2020). “You Can’t Help But Love Them”: BTS, Transcultural Fandom, and Affective Identities. Korea Journal 60(1): 100-127.

Min, W.-Jin, D. Y.-Han, B. (2018). Transcultural Fandom of the Korean Wave in Latin America: Through the Lens of Cultural Intimacy and Affinity Space. Media, Culture \& Society. First published: 14 September 2018. https://doi. org/10.1177/0163443718799403.

Nguyen, T. (2020). The Big Business of BTS, the K-Pop Band That's Changed Music. The Bangtan Boys' Brand Is Built on Authenticity and an Emotional Connection with Millions of Fans. Vox.com <https://www.vox.com/thegoods/2020/2/20/21136529/bts-billion-dollar-fandom> (accessed on: 12 June 2020).

Park, J. (2018). 'Digging Deeper into Korean Wave.' YouTube Channel DKDKTV Wants to Become Ambassador of Korean Pop Culture. The Korean Herald. $<$ http://www.koreaherald.com/view.php?ud=20181226000163> (accessed on: 12 June 2020).

Popova, M. (2020). Follow the Trope: A Digital (Auto)Ethnography for Fan Studies. In: Largent, J. E.-Popova, M.-Vist, E. (eds.), Fan Studies Methodologies. Transformative Works and Cultures 33. https://doi.org/10.3983/twc.2020.1697.

Reinhard, M. (2020). Automating Fandom: Social Bots, Music Celebrity, and Identity Online. In: Ashley Hinck, A.-Davisson, A. (eds.), Fandom and Politics - Special issue. Transformative Works and Cultures 32. https://doi. org/10.3983/twc.2020.1.

Romano, A. (2020). BTS, the Band That Changed K-Pop, Explained. The Key to BTS's Success: Emotional Resonance, Sincerity, and an ARMY of Fans. Vox - updated on: 21 February 2020. <https://www.vox.com/ 
culture/2018/6/13/17426350/bts-history-members-explained> (accessed on: 12 June 2020).

Seo, Y.-Hollingswrth, J. (2019). BTS' Army of Admirers: Inside One of the World's Most Powerful Fandoms. <https://edition.cnn.com/2019/10/12/asia/ bts-fandom-army-intl-hnk/index.html> (accessed on: 12 June 2020).

Sherliza, Moé. (2018). My Love and Hate for BTS (Extremely Cringy, Don’t Watch). $<$ https://youtu.be/JCFFkbioFsw> (accessed on: 15 October 2020). (2019). : Am I a BTS-ANTI? Fav YouTubers? Where Am I From? Q \&A \#2. $<$ https://youtu.be/H-tYUOiOT0U> (accessed on: 15 October 2020).

Song, D. (2020). Bang PD Answers the Question “What Makes BTS Different?”. $<$ https://www.koreaboo.com/stories/bang-pd-answers-question-makes-btsdifferent> (accessed on: 12 June 2020).

Tófalvi, T. (2011). Zenei közösségek és online közösségi média. A szubkultúráktól a múfaji színterekig [Music Communities and Social Media. From Subcultures to Genre Scenes]. In: Tófalvi, T.-Kacsuk, Z.-Vályi, G. (eds.), Zenei hálózatok. Zene, müfajok és közösségek az online hálózatok és az átalakuló zeneipar korában [Music, Genres, and Communities in the Age of Online Networks and a Transforming Music Industry]. Budapest: L'Harmattan, 11-39.

Trzcinska, J. (2018). Polish K-Pop Fandom. Phenomenon, Structure \& Communication. Wroclaw: The Association of Pop Culture Researchers and Pop-Cultural Education "Trickster”.

Yoon, K. (2019). Transnational Fandom in the Making: K-Pop Fans in Vancouver. International Communication Gazette 81(2): 176-192.

\section{Cite as:}

Bakó, R. K. (2020). Global Stars on Local Screens: BTS and Its "Army". Acta Universitatis Sapientiae, Communicatio 7: 171-185. DOI: 10.2478/ auscom-2020-0012. 